\title{
AUDIT SISTEM INFORMASI RUMAH SAKIT
}

\author{
NURUL AINI FADILAH \\ 165100089 \\ Fakultas Komputer \\ Nurulainifadilah.student@umitra.ac.id
}

\begin{abstract}
RS umum adalah rumah sakit yang sudah menggunakan teknologi informasi dalam pengembangan usahanya dibidang kesehatan. Salah satu pemanfaatan teknologi informasi yang digunakan adalah sistem informasi rekam medis. Dengan adanya sistem informasi rekam medis akan mempermudah dalam mengelola semua data yang terkait dengan rekam medis. Namun dengan adanya sistem informasi yang diterapkan tentunya perlu dilakukan pengamanan terhadap semua data yang dimiliki oleh RS umum. Sedangkan pemahaman dan pengetahuan tentang keamanan sistem informasi rekam medis masih kurang. Oleh karena itu untuk mendapatkan keamanan sebuah layanan sistem informasi rekam medis yang baik, maka perlu adanya audit dari sistem informasi rekam medis dengan menggunakan standar ISO 27001. Audit ini menggunakan standar ISO 27001 karena standar ini berfokus pada keamanan sistem informasi dan telah menggunakan standar nasional indonesia. Standar ini juga memiliki klausul yang lengkap untuk mengetahui keamanan sistem informasi.Penelitian ini berhasil memberikan penilaian terhadap keamanan sistem informasi rekam medis RS Umum dengan nilai maturity 2,2 (Repeatable but Intuitive). Jadi keamanan sistem informasi rekam medis RS Umum sudah cukup baik karena sudah mengikuti prosedur keamanan sistem informasi sudah yang ada. Namun pihak manajemen rumah sakit kurang memperhatikan mengenai pemahaman pentingnya keamanan sistem informasi dikalangan para pengguna atau karyawan yang menggunakan sistem informasi rekam medis.
\end{abstract}

Kata Kunci : Audit Sistem, ISO 27001 


\section{A. PENDAHULUAN}

Pemanfaatan teknologi informasi saat ini sudah tidak asing lagi dalam kehidupan kita. Mulai dari universitas, sekolah, rumah sakit, instansi pemerintahan dan berbagai perusahaan sudah memanfaatkan teknologi informasi untuk membantu mempercepat perkembangan proses bisnisnya. Salah satu instansi yang memerlukan pemanfaataan sistem informasi adalah rumah sakit. Sistem informasi rumah sakit merupakan salah satu bentuk pemanfaatan teknologi informasi yang berupa layanan perangkat lunak dalam dunia kesehatan yang digunakan di instansi rumah sakit. Dengan adanya sistem informasi rumah sakit akan mempermudah dalam mengelola semua data dari rumah sakit, seperti data rekam medis, data poliklinik, data laboratorium, data radiologi, data farmasi dan data unit unit lain di rumah sakit. Sistem informasi rumah sakit Mampu menghubungkan data - data tersebut dari setiap unit di rumah sakit. Dengan demikian proses-proses di setiap unit rumah sakit akan lebih cepat dan mudah dipantau. Sistem informasi rumah sakit juga mendukung kinerja bagian manajemen rumah sakit seperti unit SDM, kesekretariatan,administrasi, humas dan unit manajemen lain dirumah sakit. Untuk mendapatkan sebuah layanan sistem informasi rumah sakit yang baik maka perlu adanya tata kelola sistem informasi yang baik pula, termasuk didalamnya tata kelola keamanan dari sistem informasi tersebut.

\section{A. PEMBAHASAN / STUDI KASUS}

teknologi informasi saat ini sudah tidak asing lagi dalam kehidupan kita. Mulai dari universitas, sekolah, rumah sakit, instansi pemerintahan dan berbagai perusahaan sudah memanfaatkan teknologi informasi untuk membantu mempercepat perkembangan proses bisnisnya. Salah satu instansi yang memerlukan pemanfaataan sistem informasi adalah rumah sakit. Sistem informasi rumah sakit merupakan salah satu bentuk pemanfaatan teknologi informasi yang berupa layanan perangkat lunak dalam dunia kesehatan yang digunakan di instansi rumah sakit. Dengan adanya sistem informasi rumah sakit akan mempermudah dalam mengelola semua data dari rumah sakit, seperti data rekam medis, data poliklinik, data laboratorium, data radiologi, data farmasi dan data unit - unit lain di rumah sakit. Sistem informasi rumah sakit Mampu menghubungkan data - data tersebut dari setiap unit di rumah sakit. Dengan demikian 
proses-proses di setiap unit rumah sakit akan lebih cepat dan mudah dipantau. Sistem informasi rumah sakit juga mendukung kinerja bagian manajemen rumah sakit seperti unit SDM, kesekretariatan,administrasi,

humas dan unit manajemen lain dirumah sakit. Untuk mendapatkan sebuah layanan sistem informasi rumah sakit yang baik maka perlu adanya tata kelola sistem informasi yang baik pula, termasuk didalamnya tata kelola keamanan dari sistem informasi tersebut.

Salah satu metode pengelolaan keamanan sistem informasi yang sering digunakan adalah ISO 27001 (International Standar Organisation 27001). ISO 27001 merupakan dokumen standar Sistem Manajemen Keamanan Informasi (SMKI) atau Information Security Management Systems (ISMS) yang memberikan gambaran secara umum mengenai apa saja yang seharusnya dilakukan dalam usaha pengimplementasian konsepkonsep keamanan informasi di dalam sebuah perusahaan.

Penelitian tentang audit sistem informasi menggunakan standar ISO 27001 sebelumnya pernah dilakukan Ermana (2009) dengan judul Audit Keamanan Sistem Informasi Berdasarkan Standar ISO 27001 pada PT. BPR Jatim Surabaya.Penelitian ini berfokus pada keamanan sistem dengan batasan pada klausul prosedur pengelolaan aset, prosedur pengelolaan SDM, prosedur pengelolaan fisik dan lingkungan, prosedur pengamanan logical security, prosedur pengamanan operasional teknologi informasi, dan prosedur penanganan insiden dalam pengamanan informasi. Penelitian ini menghasilkan nilai maturity level sebesar 2,90 yang berarti bahwa kontrol keamanan masih berada pada level 2 planned and tracked (direncanakan dan dilacak) namun telah mendekati level 3 well defined (didefinisikan dengan baik) yang merupakan level yang diharapkan oleh perusahaan, sehingga diperlukan peningkatan kontrol keamanan.Penelitian yang berkaitan dengan audit keamanan sistem informasi dengan menggunakan standar ISO 27001 menurut peneliti belum pernah dilakukan di tempat studi kasus yaitu RSU PKU Muhammadiyah Bantul.Yang membedakan penelitian ini dengan penelitian sebelumnya adalah pengambilan studi kasus atau objek penelitian dan sasaran area kontrol pengamanan dari ISO 27001.
B. ID SECURITY QWTD4452377-ASP5244107

\section{KESIMPULAN}

Kesimpulan yang peneliti hasilkan dari proses audit sistem informasi rekam medis adalah sebagai berikut :

1. Peneliti telah berhasil 
melakukan proses audit sistem informasi rumah sakit yang mengambil studi kasus sistem informasi rekam medis RS umum dengan standar ISO 27001. Peneliti juga berhasil memberikan penilaian terhadap keamanan sistem informasi rekam medis

RS Umum 2,2 (Repeatable but Intuitive). Data ini sesuai Lampiran M Hasil Evaluasi Audit. Jadi keamanan sistem informasi rekam medis RS Umum sudah cukup baik tapi perlu meningkatkan pengelolaan aset, keamanan fisik dan lingkungan dan pengendalian akses sistem informasi rekam medis.

2. Peneliti juga telah berhasil memberikan rekomendasi untuk peningkatan keamanan sistem informasi rekam medis RS umum sesuai standar ISO 27001. Rekomendasi tersebut adalah sebagai berikut :

a. Pada klausul kontrol pengelolaan aset perlu dilakukan pengecekan inventarisasi aset oleh tim EDP dan unit Pengadaan minimal 3 (tiga) bulan sekali.
D. DISKUSI

Saya bersama teman saya bernama

Siwon

mendiskusikan tentang contoh ini dengan sangat baik Hasil diskusi dari materi ini adalah Menghasilkan penilaian tingkat keamanan sistem informasi rumah sakit sesuai standar ISO 27001.

Dan Menghasilkan rekomendasi tata kelola keamanan sistem informasi rumah sakit yang baik sesuai standar ISO 27001 


\section{E. REFERENCE}

[1] O. M. Febriani and A. S. Putra, "Sistem Informasi Monitoring Inventori Barang Pada Balai Riset Standardisasi Industri Bandar Lampung," J. Inform., vol. 13 , no. 1 , pp. 90-98, 2014.

[2] A. S. Putra, "Paperplain: Execution Fundamental Create Application With Borland Delphi 7.0 University Of Mitra Indonesia," 2018.

[3] A. S. Putra, "2018 Artikel Struktur Data, Audit Dan Jaringan Komputer," 2018.

[4] A. S. Putra, "ALIAS MANAGER USED IN DATABASE DESKTOP STUDI CASE DB DEMOS."

[5] A. S. Putra, "COMPREHENSIVE SET OF PROFESSIONAL FOR DISTRIBUTE COMPUTING."

[6] A. S. Putra, "DATA ORIENTED RECOGNITION IN BORLAND DELPHI 7.0."

[7] A. S. Putra, "EMBARCADERO DELPHI XE 2 IN GPUPOWERED FIREMONKEY APPLICATION."

[8] A. S. Putra, "HAK ATAS KEKAYAAN INTELEKTUAL DALAM DUNIA TEKNOLOGY BERBASIS REVOLUSI INDUSTRI 4.0."

[9] A. S. Putra, "IMPLEMENTASI PERATURAN

PERUNDANGAN UU. NO 31 TAHUN 2000 TENTANG DESAIN INDUSTRI BERBASIS INFORMATION
TECHNOLOGY."

[10] A "IMPLEMENTATION

[11] A A. S. Putra, Putra, OF "IMPLEMENTATION OF TRADE SECRET CASE STUDY SAMSUNG MOBILE PHONE."

[12] A. S. Putra, "IMPLEMENTATION PATENT FOR APPLICATION WEB BASED CASE STUDI WWW. PUBLIKLAMPUNG. COM."

[13] A. S. Putra, "IMPLEMENTATION SYSTEM FIRST TO INVENT IN DIGITALLY INDUSTRY."

[14] A. S. Putra, "MANUAL REPORT \& INTEGRATED DEVELOPMENT

ENVIRONMENT BORLAND DELPHI 7.0."

[15] A. S. Putra, "PATENT AS RELEVAN SUPPORT RESEARCH."

[16] A. S. Putra, "PATENT FOR RESEARCH STUDY CASE OF APPLE. Inc."

[17] A. S. Putra, "PATENT PROTECTION FOR APPLICATION INVENT."

[18] A. S. Putra, "QUICK REPORT IN PROPERTY PROGRAMMING."

[19] A. S. Putra, "REVIEW CIRCUIT LAYOUT COMPONENT REQUIREMENT ON ASUS NOTEBOOK."

[20] A. S. Putra, "REVIEW TRADEMARK PATENT FOR INDUSTRIAL TECHNOLOGY BASED 4.0."

[21] A. S. Putra, "TOOLBAR COMPONENT PALLETTE IN OBJECT 
PROGRAMMING."

[22] A. S. Putra, "WORKING DIRECTORY SET FOR PARADOX 7."

[23] A. S. Putra, "ZQUERY CONNECTION IMPLEMENTED

PROGRAMMING STUDI CASE PT. BANK BCA Tbk."

[24] A. S. Putra, D. R. Aryanti, and I. Hartati, "Metode SAW (Simple Additive Weighting) sebagai Sistem Pendukung Keputusan Guru Berprestasi (Studi Kasus: SMK Global Surya)," in Prosiding Seminar Nasional Darmajaya, 2018, vol. 1, no. 1, pp. 85-97.

[25] A. S. Putra and O. M. Febriani, "Knowledge Management Online Application in PDAM Lampung Province," in Prosiding International conference on Information Technology and Business (ICITB), 2018, pp. 181-187.

[26] A. S. Putra, O. M. Febriani, and B. Bachry, "Implementasi Genetic Fuzzy System Untuk Mengidentifikasi Hasil Curian Kendaraan Bermotor Di Polda Lampung," SIMADA (Jurnal Sist. Inf. dan Manaj. Basis Data), vol. 1, no. 1, pp. 21-30, 2018.

[27] A. S. Putra, H. Sukri, and K. Zuhri, "Sistem Monitoring Realtime Jaringan Irigasi Desa (JIDES) Dengan Konsep Jaringan Sensor Nirkabel," IJEIS (Indonesian J. Electron. Instrum. Syst., vol. 8, no. 2, pp. 221-232.

[28] D. P. Sari, O. M. Febriani, and

A. S. Putra, "Perancangan
Sistem Informasi SDM Berprestasi pada SD Global Surya," in Prosiding Seminar Nasional Darmajaya, 2018, vol. 1, no. 1, pp. 289-294. 